Research Square

\title{
Untreated dental caries prevalence and impact on the quality of life among 11 to 14-year-old Egyptian schoolchildren: A cross-sectional study
}

\author{
Samar Eid \\ Ministry of health and population, Egypt \\ Nagwa Khattab \\ Minia University Faculty of Dentistry \\ Ahmad Elheeny ( $\square$ ahmed.elheny@yahoo.com ) \\ Faculty of Dentistry Mina University Egypt https://orcid.org/0000-0001-7796-0198
}

\begin{abstract}
Research article
Keywords: Adolescent, oral health, dental caries, quality of life
\end{abstract}

Posted Date: March 13th, 2020

DOI: https://doi.org/10.21203/rs.2.18719/v3

License: (c) (i) This work is licensed under a Creative Commons Attribution 4.0 International License. Read Full License

Version of Record: A version of this preprint was published at BMC Oral Health on March 19th, 2020. See the published version at https://doi.org/10.1186/s12903-020-01077-8. 


\section{Abstract}

Background This study aimed to assess caries prevalence and experience among 11 to 14 years, school children, analyze demographic, socioeconomic, personal and professional dental care in relation to untreated carious lesions, and evaluates the effect of decayed teeth on early adolescents' oral health-related quality of life (OHRQoL).

Methods A cross-sectional analytical investigation was conducted on 1020 preparatory schoolchildren selected on the basis of a multistage sampling technique. Caries status of the participants detected via recording their caries experience and untreated cavities using DMFT and DT indices. OHRQoL was determined using a validated Arabic CPQ 11-14 short-form questionnaire. Statistical methods for descriptive analysis, chi-square test, Independent-Samples t test and one-way analysis of variance (ANOVA) were used. Multivariate Poisson regression analysis through a hierarchical approach was used to detect the influence of independent variables on DT scores. To declare the association between independent variables and QoL, a step-by-step, multivariate regression analysis was conducted.

Results The average scores of DMFT and DT in this study were $2.97 \pm 1.29$ and $1.66 \pm 1.24$. Poisson regression analysis demonstrated that early adolescents whom their mothers with a lower level of education and of low socioeconomic status were 1.41 and 1.27 times respectively had higher DT scores when compared with their peers. Untreated cavities affected mainly by mother education, school type, family income, and regular dental appointments. Children with DMFT $\leq 3$ ) or DT=0 recorded a statistically significant lower CPQ 11-14 average score ( $\mathrm{p} \otimes 0.01)$ and ( $\mathrm{p} \otimes 0.0001)$ respectively.

Conclusions Untreated carious cavities and caries experience were associated with lower socioeconomic, maternal education andl ess frequent tooth brushing. Untreated carious cavities have a significant negative impact on schoolchildren's QoL. .

\section{Background}

Dental caries is one of the global health issues in both industrialized and developing communities. However, dental caries incidence and prevalence is more pronounced in developing countries like Egypt [1, 2]. Dental caries is an age-related disease involving about $60-90 \%$ of schoolchildren [1,3]. Caries is an outcome of several interplaying factors such as cultural, social, and political factors which in turn rule the individual behaviors and commitment to preventive oral hygiene measures [4]. Dental caries studying has a raised attention in a critical life-stage like adolescence because caries progression increases at this stage [5]. In addition, at this stage good oral hygiene, proper diet and regular dental check-up behaviors should be enforced. Untreated carious cavities especially when associated with pain may influence children's' physical and psychological development as well as school and daily-life achievements [6]. Plenty of studies revealed the association between oral health and adolescent's quality of life (QoL) physical, psychological, social and emotional aspects $[7,8]$. One of the tools designed by Jokovic et al. to measure the oral-health related quality of life (OHRQoL) in children is a child perception questionnaire for 11-14 years age group $\left(\mathrm{CPQ}_{11-14}\right)$ short form [9]. OHRQoL has a multidimensional structure to measure different aspects of oral health in a subjective way including oral symptoms, functional limitations, emotional and functional well-being [10]. Caries prevalence among Egyptian inhabitance is high [1]. The number of investigations conducted in Egypt especially among the early adolescents age group is limited. Moreover, up to the available data, the relation between decayed teeth and OHRQoL among teenagers Egyptian students is still not clarified.

The current study aimed to (1) assess caries prevalence and experience among 11-14 years schoolchildren, (2) analyze demographic, socioeconomic, personal and professional dental care in relation to untreated carious lesions, (3) evaluate the effect of decayed teeth on early adolescents' OHRQoL.

\section{Methods}

\section{Design, setting and sampling}

This cross-sectional analytical study conducted in Minia City, Upper Egypt between September 2016 and April 2019. The needed number of children participating in the study was 927 , which calculated on the basis of the following formula [11]; $N=\left(Z_{a / 2}\right)^{2} s^{2} / d^{2}$, where $(N)$ is the number of participants and $(d)$ is the degree of precision adjusted at $0.05(5 \%)$, and the $Z_{\alpha / 2}$ was $1.65 \mathrm{~A}$ pilot study conducted before launching the procedures on 56 children aged from 12 to 14 years and the standard deviation (s) of DMFT was 0.92 . The total sample size was 1020 children after adding $10 \%$ to compensate the drop-off. After obtaining the necessary permissions from the Ministry of Education, the sampling process has been launched. The type of sample adopted in this study was a multistage stratified 
random sample. The selected strata based on gender (males and females), school type (public, private) and finally the school district (North, South, East and West). Details of sampling procedures illustrated in figure 1.

\section{Eligibility criteria}

Children aged from 11 to 14 years should fulfill the following criteria; (1) No orthodontic treatment or malocclusion or severe gingival or periodontal diseases. (2) Absence of any systemic, emotional or intellectual disabilities. (3) No emergency dental recall in the last three months reference

\section{Study variables}

An anonymous questionnaire using a face-to-face interview has been adopted in this study. The questionnaire was divided into 2 principal sections; the first section included the following variables; (1) demographic data; (a) gender and (b) age, (2) socioeconomic data (a) mother's level of education; dichotomized according to the number of education years into $\geq 9$ years (greater than secondary and secondary school) and $₫ 9$ years (less than secondary school or illiterate), (b) school type; classified into public and private schools, (c) household expenditures which recorded according to the cut-off poverty line in Egypt which is 3.20 US\$ per day and [12, 13] , (3) dental self-care and use of dental services; (a) frequency of tooth brushing with fluoridated toothpaste, (b) frequency of fluoridated mouth rinse use. The response of both ' $a$ ' and ' $b$ ' dichotomized into regular use (frequency is $\geq 1$ time per day) and irregular (no tooth brushing or mouth wash use or $\leq 3$ times per week), (c) use of dental floss, (d) Do you regulary visit the dentist for regular check -up per year dichotomized into (yes or no). (4) clinical oral examination and recording dental caries status through recording the decayed, missing, filled teeth (DMFT) index for permanent teeth according to data into ( $\leq 3$ and $\otimes 3$ ) based on the global target of score three announced by World health organization (WHO) for the year 2000 [14]. Untreated carious cavity scores "i.e. Decayed tooth (DT) index" dichotomized into 0 and $\geq 1$. The second section concerned with evaluating the OHRQoL using a previously validated Arabic version of $\mathrm{CPQ}_{11-14}$ short-form consisted of 16 questions (4 questions of each domain). The 4 domains assessed firstly, the oral symptoms (OS) included questions about pain in teeth/mouth, bad breath, mouth sore and food caught between teeth. The second domain assessed the functional limitation (FL). For instance, the difficulty in chewing of firm food or saying words, sleeping problems and longer time has been taken to eat a meal. The third domain evaluated the emotional well-being (EW) through questions concerned whether the participants felt upset, shy, frustrated or concerned what people think about his/her teeth. Finally, the social well-being (SW) domain illustrated through 4 questions (teased/called names, avoided smiling/laughing, argued with children/family and not wanted to speak/read loud in class). Response scores graduated on a 4-Likert point scale; (0) never, (1) once or twice, (2) sometimes, (3) often and (4) every day or almost every day. The minimum score was 0 and the maximum score was 64 .Another one self-perception question reported by each participant about his/her OHRQoL evaluation $[9,15]$.

\section{Calibration, pilot study, and data collection}

Firstly, two dentists with at least two years of residency at the Pediatric and Dental Public Health Department, Faculty of Dentistry, Minia University, trained for two weeks for calibration. The second step was conducting a pilot study on 67 children. The pilot study aimed to determine QoL mean and standard deviation required for sample size calculation and to test the intraexaminer and inter-examiner reliability. The results of the pilot study did not include in the final statistical analysis. Dental caries examination performed at two appointments with one-week interval. The clinical examination carried out using a visual-tactile method using a dental mirror and WHO probe five seconds per dental surface under artificial light use [16].

\section{Statistical methods}

A Statistical Program Statistical Package for the Social Sciences (SPSS) version 20 has been used for statistical analysis. Data normality was examined and descriptive analysis including frequency tables, chi-square test for categorical variables, IndependentSamples T-Test and one-way analysis of variance (ANOVA) to compare $\mathrm{CPQ}_{11-14}$ overall score means of independent predictors. The mean/standard deviation, and median/Interquartile range (IQR) of the $\mathrm{CPQ}_{11-14}$ different domains were calculated. Univariate Poisson regression analysis was performed to determine the associations between decayed teeth (i.e. outcome variable) and demographic, socioeconomic, dental care and oral health related quality of life self-perception independent predictors. Predictors with a significant level exceeding $0.2(p \otimes 0.2)$ were excluded from the final adjusted multivariate regression model. A conceptual model was released according to a hierarchy approach of determinants and risk factors and it was structured according to the model made by Paula et al. as shown in figure 2 [17]. Predictors categorized into four modelsModel 1 included gender, Model 2 incorporated model 1 plus 
socioeconomic variables Model 3 contained Model 2 plus child's dental care and Model 4 implicated model 3 plus child's oral healthrelated quality of life self-perception.

To declare the association between independent variables and QoL, a step-by-step, multivariate linear regression analysis was

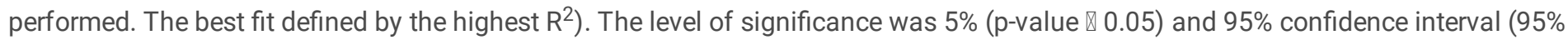
$\mathrm{Cl})$.

\section{Results}

Intra and inter-observer reliability; Kappa coefficients (к) were 0.91 and 0.86 for intra-examiner and inter-examiner reliability respectively. More than two-thirds of participants are from the public. The prevalence of dental caries among school children (DT $\geq 1$ ) was $58.5 \%$. Approximately half of the participants showed caries experience exceeded scores three (DMFT囚3). The socioeconomic status displayed that more than two thirds of the participants' mothers had at least nine years of education (72.1\%) and approximately one half the teenager's family income was below the cut-off point of poverty (46.4\%). The majority of the teenagers did not use mouthwash or dental floss ( $84.8 \%$ and $87 \%$ respectively). Concerning tootbrushing using a fluoridated tooth paste, only $30.1 \%$ of the participants were brushing their teeth on a regular basis (2 times daily) (Table 1 ).

The average scores of DMFT and DT in this study were $2.97 \pm 1.29$ and $1.66 \pm 1.24$. Caries experience showed no statistically significant difference between males and females. Maternal education, school type as an indicator of economic status, regular toothbrush and professional check-up revealed a significant impact on DMFT and DT scores $(p \otimes 0.001)$ (Table 2).

Poisson regression analysis demonstrates that early adolescents whom their mothers with a lower level of education and of low socioeconomic status were 1.41 and 1.27 times respectively had higher DT scores when compared with their peers. Untreated cavities affected mainly by the mother education, school type, family income and regular dental appointments (Table 3).

Females report a higher score of $\mathrm{CPQ}_{11-14}$ means, indicating lower satisfaction with their OHRQoL than male counterparts ( $\left.\mathrm{p} \otimes 0.0001\right)$. Regarding caries status, both caries experience (DMFT $\leq 3)$ and decayed teeth score (DT $=0)$ record a statistically significant lower $C P Q_{11-14}$ average scores $(p \otimes 0.01)$ and $(p \otimes 0.0001)$ respectively than those with higher DMFT and DT scores (Table 4).

Oral symptoms domain especially, pain figures out the highest mean scores (11.16 \pm 3.58$)$ among $C P Q_{11-14}$ different domains. Functional limitations, emotional well-being, and social well-being domains average scores are illustrated in table 5.

Multiple regression analysis showed that untreated carious lesions (DT), socioeconomic status and constant toothbrush explain $64 \%$ of the variance in participant's QoL (Table 6).

\section{Discussion}

Dental caries may have negative impacts, especially on early adolescence life, through reducing the efficiency of masticatory function and general appearance which is reflected in growth and development as it affects emotional and social health. The current observational cross-sectional study intended to assess the caries experience and its impact on OHRQL among a group of Egyptian school children aged from 12 to 14 years. This age group has been chosen to carry out this study based on the following aspects; (1) caries rate is higher among children [18], (2) this age group is the WHO target group for dental caries global comparison [14]. Data gathered through a face-to-face interviews to eschew data missing, reduce information bias and enhance the accuracy of data [19]. The response rate was $87 \%$, this may be related to the use of anonymous $\mathrm{CPQ}_{11-14}$ questionnaire which also guarantees the participant's confidentiality.

Although the flood of data concerning the worldwide caries experience at various age groups, it still a significant issue to concern. Up to the available data, studies measuring caries experience among 11 to 14 -year-old students were limited. Moreover, this work is leading research in studying the association between caries and OHRQoL among early adolescent Egyptian students. The mean DMFT scores in this study were $2.97 \pm 1.29$ which within does approximately similar to the DMFT target declared by the World Health Organization (WHO) in 2000 [14]. Untreated cavities mean values were higher among girls than boys. This difference may be attributed to the higher commitment of girls toward oral hygiene habits like tooth brushing than boys. This finding was in agreement with prior studies [1,20]. The River Nile is the main source of water in the Egypt. the fluoride contents of Nile waters fluctuate between 0.2 and $0.4 \mathrm{mg}-\mathrm{F} / \mathrm{L}$ of average of $0.34 \mathrm{mg}-\mathrm{F} / \mathrm{L}$. As Minia As it is located in the Upper Egypt where the weather is hot and subsequently the water consumption 
increases this beside of the habit of drinking tea and the use of water in cooking is common, So the final consumption of water which come from the River Nile was about $0.7 \mathrm{mg}-\mathrm{F} / \mathrm{L}$ which compatible with the optimum level of Fluoride announced by The WHO which ranged from 0.7 to $1.2 \mathrm{mg}-\mathrm{F} / \mathrm{L}$ [21]. Despite of water fluoridation in Egypt provides the optimum level of fluoride and No outsources are required, the caries prevalence in the current study was high and this may be related to the complex nature of the disease which requires a multidisciplinary approach for its prevention. In the present study, caries experience was higher than that reported by two former studies conducted in a nearly similar Egyptian age group. The first study performed in 2011, on 976 schoolchildren [2]. The average DMFT score was $1.68 \pm 1.92$, and this may be assigned to the use of a distinct sampling method which relied on choosing only two public schools (one for boys and the other for girls) from the Giza governorate. In addition, school enrollment of children in Egypt depends fundamentally on geographic distribution. Therefore, the approach might consider children who nearly have similar socioeconomic and parents' educational backgrounds. The DMFT score of the other study published in 2019, was also lesser than the results of the current study $(1.68 \pm 1.92)$ [1]. The reason may be due to the difference between the two studies in sample size. Caries prevalence of untreated carious cavities in the present study was $58.5 \%$ which was higher than that reported by a pontigo-loyola et al. who reported a caries prevalence of $48.6 \%$ among 12 and 15 age children in high altitudes [22]. The difference may be related to the higher community water fluoridation which surpassed the systemic water fluoridation in Egypt. The findings of skinner et al. published a caries prevalence of $45 \%$ among 14- and 15-year-olds in New South Wales, Australia [23]. In comparison, global DMFT scores reported in other countries showed a wide range of diversity. Some researches revealed lower DMFT scores than the finding of the current research [24-28]. Other research reported nearly similar results [29-31]. While a number of researches recorded higher DMFT scores [14, 32, 33]. This wide range of diversity attributed to the differences in study designs, sample sizes, eating habits and socioeconomic and cultural backgrounds. In the current study, children with lower DMFT and DT scores were belonging to families with higher income as well as education level in comparison to children with high caries experience. This inverse relationship between DMFT scores and both maternal education level and economic status denotes their significant impact on caries experience. Several previous studies confirmed this relationship [34-36]. Lower socioeconomic status might hinder the adherence to preventive interventions such as tooth brushing and regular professional dental examination which consistent with other studies. Moreover, these associations were also evident with untreated carious cavities [37].

Dental caries has a negative impact on the adolescent's QoL. The present study utilized $\mathrm{CPQ}_{11-14}$ short form which reported by Jokovic et al. to have excellent validity and maintained its multidimensional properties [9]. Direct comparison between the results of this study and the findings of global researches concerned with the impact of caries on OHRQoL may be influenced with the diversity of socioeconomic, traditions and cultural backgrounds. However, it was salutary to consider some of these studies. In the present, oral symptoms especially pain demonstrated the highest mean scores which demonstrated the prominent influence on eating, speaking and sleeping aspects. These were in agreement with the findings of former studies [38, 39]. Untreated carious lesions can lead to what can be called a "vicious cycle" because pain or teeth loss as a result of the carious tooth will reduce the mastication performance due to the difficulty in hard food chewing and subsequently, a shift toward more soft and processed food will take place. This food usually more cariogenic and of little nutritional benefits which will increase the caries progression and subsequent increase in more soft food consumption. Another negative aspect of soft and highly processed foods is their passive effect on children's growth and development $[40,41]$. Unfortunately, oral symptoms not the only consequences of pain or missing teeth due to decay in this study, but also, the emotional effect on the participants in this study was announced. This can be explained by the undermining of children's self-esteem due to altered eating, chewing, speaking and social appearance [41, 42]. The current study emphasized the connection between low socioeconomic status and OHRQoL. The education level of mothers and financial status plays a vital role in an individual's lifestyle decisions and adherence to routine preventive measures such as tooth brushing and get access to dental services.

The findings of this study spotlight the importance of adopting strategies aimed to increase awareness about oral health among mothers and school children at this age and emphasize the importance of oral hygiene habits. It is also recommended to reduce socioeconomic inequalities.

The present study has a number of strong features such as the representative sample, high response rate as well as intra-examiner and inter-examiner reliability. All of these points are positively reflected in the study generalization as well as its internal validity. On the other hand, the main weak point in this study was attributed to the cross-sectional design as data collected at one point of time in contrast to the prospective design.

\section{Conclusions}


The present study clarifies that more than half of schoolchildren aged from 11- to 14-years showed untreated cavities. This may declare the negative impact of untreated carious lesions and negative QoL. However, caries experience recorded no significant alliance with OHRQoL. Both untreated cavities and caries experience were significantly associated with lower household expenditure, lower maternal education and irregular adherence to tooth brushing habit. Oral symptoms were the chief domains that adversely influencing early adolescent's OHRQoL. Further studies especially the longitudinal study are required to assess the correlation between these different variables and OHRQoL different aspects.

\section{Declarations}

\section{Ethics approval and consent to participate}

This study reviewed and signed by the Ethics Committee of Faculty of Dentistry, Minia University (registration number 174/2015). The current study conducted in full accordance with the World Medical Association Declaration of Helsinki. All participants or their legal guardians signed the informed consent form before participating in any part of the research

\section{Consent for publication}

All authors give the ptheir acceptance for publication of that work in BMC Oral Health

\section{Availability of data and material}

Not applicable

\section{Competing interests}

Authors declare that they have no conflict of interest.

\section{Funding}

The search was self-funded and other sources for funding for the research

\section{Authors' contributions}

Author EAA was responsible for the research idea, paper writing and formatting and statistical analysis. Author ES was responsible for the clinical aspects of the study and data gathering. Author KN was responsible for revising the work

\section{Acknowledgments}

The author is deeply appreciated to all participants and their parents for their full cooperation to conduct this work. In addition, I would like to thank the Paediatric residents AMM and EKM in Paediatric Dentistry Department for their crucial contribution to oral examination and data recording. In addition, the author appreciates all the staff members and the nursing staff at the Paediatric Dentistry Department, Faculty of Dentistry, Minia University for their help and care of our precious children.

\section{References}

1. Abbass MMS, Mahmoud SA, El Moshy S, Rady D, AbuBakr N, Radwan IA, Ahmed A, Abdou A, Al Jawaldeh A: The prevalence of dental caries among Egyptian children and adolescences and its association with age, socioeconomic status, dietary habits and other risk factors. A cross-sectional study. F1000Res 2019, 8:8.

2. Mobarak EH, Shabayek MM, Mulder J, Reda AH, Frencken JE: Caries experience of Egyptian adolescents: does the atraumatic restorative treatment approach offer a solution? Med Princ Pract 2011, 20(6):545-549.

3. Petersen PE: The burden of oral disease: challenges to improving oral health in the 21st century. Bull World Health Organ 2005, 83(1):3.

4. Ortiz AS, Tomazoni F, Knorst JK, Ardenghi TM: Influence of socioeconomic inequalities on levels of dental caries in adolescents: A cohort study. Int J Paediatr Dent 2019.

5. Merdad L, El-Housseiny AA: Do children's previous dental experience and fear affect their perceived oral health-related quality of life (OHRQoL)? BMC Oral Health 2017, 17(1):47. 
6. Mota-Veloso I, Soares ME, Alencar BM, Marques LS, Ramos-Jorge ML, Ramos-Jorge J: Impact of untreated dental caries and its clinical consequences on the oral health-related quality of life of schoolchildren aged 8-10 years. Qual Life Res 2016, 25(1):193-199.

7. Akesson ML, Warnberg Gerdin E, Soderstrom U, Lindahl B, Johansson I: Health-related quality of life and prospective caries development. BMC Oral Health 2016, 16:15.

8. Kastenbom L, Falsen A, Larsson P, Sunnegardh-Gronberg K, Davidson T: Costs and health-related quality of life in relation to caries. BMC Oral Health 2019, 19(1):187.

9. Jokovic A, Locker D, Guyatt G: Short forms of the Child Perceptions Questionnaire for 11-14-year-old children (CPQ11-14): development and initial evaluation. Health Qual Life Outcomes 2006, 4:4.

10. Sischo L, Broder HL: Oral health-related quality of life: what, why, how, and future implications. J Dent Res 2011, 90(11):1264-1270.

11. Suresh K, Chandrashekara S: Sample size estimation and power analysis for clinical research studies. J Hum Reprod Sci 2012, 5(1):7-13.

12. Fosu AK: Inequality, income, and poverty: comparative global evidence. Soc Sci Q 2010, 91(5):1432-1446.

13. Mowafi M, Khadr Z, Kawachi I, Subramanian SV, Hill A, Bennett GG: Socioeconomic status and obesity in Cairo, Egypt: a heavy burden for all. J Epidemiol Glob Health 2014, 4(1):13-21.

14. Al-Darwish M, El Ansari W, Bener A: Prevalence of dental caries among 12-14 year old children in Qatar. Saudi Dent J 2014, 26(3):115-125.

15. Brown A, Al-Khayal Z: Validity and reliability of the Arabic translation of the child oral-health-related quality of life questionnaire (CPQ11-14) in Saudi Arabia. Int J Paediatr Dent 2006, 16(6):405-411.

16. Assaf AV, Meneghim Mde C, Zanin L, Mialhe FL, Pereira AC, Ambrosano GM: Assessment of different methods for diagnosing dental caries in epidemiological surveys. Community Dent Oral Epidemiol 2004, 32(6):418-425.

17. Paula JS, Ambrosano GM, Mialhe FL: The impact of social determinants on schoolchildren's oral health in Brazil. Braz Oral Res 2015, 29:1-9.

18. Clinical Affairs Committee AAoPD: Guideline on Adolescent Oral Health Care. Pediatr Dent 2015, 37(5):49-56.

19. Khattab NMA, Elheeny AAH, Tony GA: Oral-cancer knowledge, practice, and attitude assessment of dentists in Upper Egypt: A crosssectional study. Clin Exp Dent Res 2019, 5(2):121-127.

20. Mamai-Homata E, Koletsi-Kounari H, Margaritis V: Gender differences in oral health status and behavior of Greek dental students: A meta-analysis of 1981, 2000, and 2010 data. J Int Soc Prev Community Dent 2016, 6(1):60-68.

21. Emslie RD: A dental health survey in the Republic of the Sudan. Br Dent J 1966, 120(4):167-178.

22. Pontigo-Loyola AP, Medina-Solis CE, Borges-Yanez SA, Patino-Marin N, Islas-Marquez A, Maupome G: Prevalence and severity of dental caries in adolescents aged 12 and 15 living in communities with various fluoride concentrations. J Public Health Dent 2007, 67(1):8-13.

23. Skinner J, Johnson G, Phelan C, Blinkhorn A: Dental caries in 14- and 15-year-olds in New South Wales, Australia. BMC Public Health 2013, 13:1060.

24. Christian B, Ummer-Christian R, Blinkhorn A, Hegde V, Nandakumar K, Marino R, Chattopadhyay A: An epidemiological study of dental caries and associated factors among children residing in orphanages in Kerala, India: Health in Orphanages Project (HOPe). Int Dent J 2019, 69(2):113-118.

25. Nurelhuda NM, Trovik TA, Ali RW, Ahmed MF: Oral health status of 12-year-old school children in Khartoum state, the Sudan; a school-based survey. BMC Oral Health 2009, 9:15.

26. Ahmed NA, Astrom AN, Skaug N, Petersen PE: Dental caries prevalence and risk factors among 12-year old schoolchildren from Baghdad, Iraq: a post-war survey. Int Dent J 2007, 57(1):36-44.

27. Masood M, Yusof N, Hassan Ml, Jaafar N: Longitudinal study of dental caries increment in Malaysian school children: a 5-year cohort study. Asia Pac J Public Health 2014, 26(3):260-267.

28. Campus G, Cagetti MG, Senna A, Sacco G, Strohmenger L, Petersen PE: Caries prevalence and need for dental care in 13-18-yearolds in the Municipality of Milan, Italy. Community Dent Health 2008, 25(4):237-242.

29. Jamelli SR, Rodrigues CS, de Lira PI: Nutritional status and prevalence of dental caries among 12-year-old children at public schools: a case-control study. Oral Health Prev Dent 2010, 8(1):77-84.

30. Pakpour AH, Hidarnia A, Hajizadeh E, Kumar S, Harrison AP: The status of dental caries and related factors in a sample of Iranian adolescents. Med Oral Patol Oral Cir Bucal 2011, 16(6):e822-827. 
31. Al-Mutawa SA, Shyama M, Al-Duwairi Y, Soparkar P: Dental caries experience of Kuwaiti schoolchildren. Community Dent Health 2006, 23(1):31-36.

32. Delgado-Angulo EK, Hobdell MH, Bernabe E: Poverty, social exclusion and dental caries of 12-year-old children: a cross-sectional study in Lima, Peru. BMC Oral Health 2009, 9:16.

33. Hysi D, Caglar E, Droboniku E, Toti C, Kuscu OO: Dental caries experience among Albanian pre-school children: a national survey. Community Dent Health 2017, 34(1):46-49.

34. Oliveira LB, Sheiham A, Bonecker M: Exploring the association of dental caries with social factors and nutritional status in Brazilian preschool children. Eur J Oral Sci 2008, 116(1):37-43.

35. Pattussi MP, Marcenes W, Croucher R, Sheiham A: Social deprivation, income inequality, social cohesion and dental caries in Brazilian school children. Soc Sci Med 2001, 53(7):915-925.

36. Piovesan C, Mendes FM, Antunes JL, Ardenghi TM: Inequalities in the distribution of dental caries among 12-year-old Brazilian schoolchildren. Braz Oral Res 2011, 25(1):69-75.

37. Polk DE, Weyant RJ, Manz MC: Socioeconomic factors in adolescents' oral health: are they mediated by oral hygiene behaviors or preventive interventions? Community Dent Oral Epidemiol 2010, 38(1):1-9.

38. Bastos RS, Carvalho ES, Xavier A, Caldana ML, Bastos JR, Lauris JR: Dental caries related to quality of life in two Brazilian adolescent groups: a cross-sectional randomised study. Int Dent J 2012, 62(3):137-143.

39. Jurgensen N, Petersen PE: Oral health and the impact of socio-behavioural factors in a cross sectional survey of 12-year old school children in Laos. BMC Oral Health 2009, 9:29.

40. Lima SLA, Santana CCP, Paschoal MAB, Paiva SM, Ferreira MC: Impact of untreated dental caries on the quality of life of Brazilian children: population-based study. Int J Paediatr Dent 2018, 28(4):390-399.

41. Gilchrist F, Marshman Z, Deery C, Rodd HD: The impact of dental caries on children and young people: what they have to say? Int $J$ Paediatr Dent 2015, 25(5):327-338.

42. Kaur P, Singh S, Mathur A, Makkar DK, Aggarwal VP, Batra M, Sharma A, Goyal N: Impact of Dental Disorders and its Influence on Self Esteem Levels among Adolescents. J Clin Diagn Res 2017, 11(4):ZC05-ZC08.

\section{Tables}

Table 1. Frequency of demographic, socioeconomic, dental care, relation caries experience (DMFT) and decayed teeth (DT) 


\begin{tabular}{|c|c|}
\hline Predictors & N (\%) \\
\hline $\begin{array}{l}\text { Gender } \\
\text { Male } \\
\text { Female }\end{array}$ & $\begin{array}{l}575(56.4) \\
445(43.6)\end{array}$ \\
\hline $\begin{array}{l}\text { Age (years) } \\
12 \\
13 \\
14 \\
\end{array}$ & $\begin{array}{l}323(31.6) \\
299(293) \\
398(39.1)\end{array}$ \\
\hline $\begin{array}{l}\text { School type } \\
\text { Public } \\
\text { Private }\end{array}$ & $\begin{array}{l}721(70.7) \\
299(29.3)\end{array}$ \\
\hline $\begin{array}{l}\text { Mother education (years) } \\
\geq 9 \\
\square 9\end{array}$ & $\begin{array}{l}735(72.1) \\
285(27.9)\end{array}$ \\
\hline $\begin{array}{l}\text { Household expenditure } \\
\square 3.20 \$ / \text { day } \\
\leq 3.20 \text { \$day }\end{array}$ & $\begin{array}{l}547(53.6) \\
473(46.4)\end{array}$ \\
\hline $\begin{array}{l}\text { Tooth brushing frequency } \\
\text { Irregular } \\
\text { Regular }\end{array}$ & $\begin{array}{l}713(69.9) \\
307(30.1) \\
\end{array}$ \\
\hline $\begin{array}{l}\text { Mouth washing frequency } \\
\text { Irregular } \\
\text { Regular }\end{array}$ & $\begin{array}{l}865(84.8) \\
155(15.2) \\
\end{array}$ \\
\hline $\begin{array}{l}\text { Dental appointment per year } \\
\text { No } \\
\text { Yes }\end{array}$ & $\begin{array}{l}671(65.8) \\
349(34.2)\end{array}$ \\
\hline $\begin{array}{l}\text { Dental floss use } \\
\text { No } \\
\text { Yes }\end{array}$ & $\begin{array}{l}887(87.0) \\
133(13.0) \\
\end{array}$ \\
\hline $\begin{array}{l}\text { DMFT } \\
\leq 3 \\
\square 3\end{array}$ & $\begin{array}{l}513(50.3) \\
507(49.7)\end{array}$ \\
\hline $\begin{array}{l}\text { DT } \\
0 \\
\geq 1 \\
\end{array}$ & $\begin{array}{l}423(41.5) \\
597(58.5) \\
\end{array}$ \\
\hline
\end{tabular}

Table 2. Frequency of demographic, socioeconomic, dental care, in relation caries experience (DMFT) and untreated decayed teeth (DT) 


\begin{tabular}{|c|c|c|c|c|c|c|}
\hline \multirow[t]{2}{*}{ tors } & \multicolumn{2}{|l|}{ DT } & \multirow[b]{2}{*}{$p$-value* } & \multicolumn{2}{|l|}{ DMFT } & \multirow[b]{2}{*}{$p$-value ${ }^{*}$} \\
\hline & $\begin{array}{l}\mathrm{DT}=0 \\
\mathrm{~N}(\%)\end{array}$ & $\begin{array}{l}\mathrm{DT} \geq 1 \\
\mathrm{~N}(\%)\end{array}$ & & $\begin{array}{l}\text { DMFT } \leq 3 \\
N(\%)\end{array}$ & $\begin{array}{l}\text { DMFTロ3 } \\
\mathrm{N}(\%)\end{array}$ & \\
\hline $\mathrm{r}$ & $\begin{array}{l}104(10.2) \\
187(18.3)\end{array}$ & $\begin{array}{l}471(46.1) \\
258(25.3)\end{array}$ & $\square 0.0001$ & $\begin{array}{l}326(32) \\
261(25.6)\end{array}$ & $\begin{array}{l}249(24.4) \\
184(18)\end{array}$ & 0.53 \\
\hline ears) & $\begin{array}{l}106(10.4) \\
88(8.6) \\
99(9.7)\end{array}$ & $\begin{array}{l}217(21.3) \\
211(20.7) \\
299(29.3)\end{array}$ & 0.06 & $\begin{array}{l}191(18.7) \\
179(17.5) \\
217(21.3)\end{array}$ & $\begin{array}{l}132(12.9) \\
120(11.8) \\
181(17.7)\end{array}$ & 0.29 \\
\hline $\begin{array}{l}\text { l type } \\
\text { e }\end{array}$ & $\begin{array}{l}136(13.3) \\
155(15.2)\end{array}$ & $\begin{array}{l}585(57.4) \\
141(13.8)\end{array}$ & $\square 0.0001$ & $\begin{array}{l}213(20.9) \\
179(17.5)\end{array}$ & $\begin{array}{l}508(49.8) \\
120(11.8)\end{array}$ & 0.001 \\
\hline r education (years) & $\begin{array}{l}423(41.5) \\
85(8.3)\end{array}$ & $\begin{array}{l}312(30.6) \\
200(19.6)\end{array}$ & $\square 0.0001$ & $\begin{array}{l}513(50.3) \\
170(16.7) \\
\end{array}$ & $182(17.8) 115(11.3)$ & $\square 0.0001$ \\
\hline $\begin{array}{l}\text { hold expenditure } \\
\text { /day } \\
\text { \$/day }\end{array}$ & $\begin{array}{l}255(25) \\
134(13.1)\end{array}$ & $\begin{array}{l}292(28.6) \\
339(33.2)\end{array}$ & 0.01 & $\begin{array}{l}323(31.7) \\
264(25.9)\end{array}$ & $\begin{array}{l}224(22) \\
209(20.5)\end{array}$ & 0.29 \\
\hline $\begin{array}{l}\text { brushing frequency } \\
\text { lar } \\
\text { ir }\end{array}$ & $\begin{array}{l}125(12.3) \\
176(17.3)\end{array}$ & $\begin{array}{l}588(57.6) \\
131(12.8)\end{array}$ & $\square 0.0001$ & $\begin{array}{l}330(32.4) \\
204(20)\end{array}$ & $\begin{array}{l}383(37.5) \\
103(10.1)\end{array}$ & $\square 0.0001$ \\
\hline $\begin{array}{l}\text { washing frequency } \\
\text { lar } \\
\text { ir }\end{array}$ & $\begin{array}{l}268(26.3) \\
23(2.3) \\
\end{array}$ & $\begin{array}{l}686(67.3) \\
43(4.2) \\
\end{array}$ & 0.24 & $\begin{array}{l}358(35.1) \\
93(9.1)\end{array}$ & $\begin{array}{l}507(49.7) \\
62(6.1) \\
\end{array}$ & 0.34 \\
\hline appointment per year & $\begin{array}{l}136(13.3) \\
196(19.2)\end{array}$ & $\begin{array}{l}535(52.5) \\
153(15)\end{array}$ & $\square 0.0001$ & $\begin{array}{l}267(26.2) \\
214(20.1)\end{array}$ & $\begin{array}{l}404(39.6) \\
135(13.2)\end{array}$ & $\square 0.0001$ \\
\hline floss use & $\begin{array}{l}260(28.4) \\
30(2.9)\end{array}$ & $\begin{array}{l}597(58.5) \\
103(10.1)\end{array}$ & 0.07 & $\begin{array}{l}372(36.5) \\
72(7.1)\end{array}$ & $\begin{array}{l}515(50.5) \\
61(5.9)\end{array}$ & 0.39 \\
\hline
\end{tabular}

*Chi-square test

Table 3. Poisson analysis for decayed teeth (DT) in relation to demographic, socioeconomic and dental care 


\begin{tabular}{|c|c|c|c|c|c|c|c|c|c|c|}
\hline \multirow[t]{2}{*}{ ?redictors } & \multicolumn{2}{|c|}{ Univariate analysis } & \multicolumn{2}{|l|}{ Model 1} & \multicolumn{2}{|l|}{ Model 2} & \multicolumn{2}{|l|}{ Model 3} & \multicolumn{2}{|l|}{ Model 4} \\
\hline & $\begin{array}{l}\text { Unadjusted PR } \\
95 \% \text { CI }\end{array}$ & $\begin{array}{l}p \text { - } \\
\text { value }\end{array}$ & $\begin{array}{l}\text { Adjusted PR } \\
95 \% \text { CI }\end{array}$ & $\begin{array}{l}p \text { - } \\
\text { value }\end{array}$ & $\begin{array}{l}\text { Adjusted PR } \\
95 \% \text { CI }\end{array}$ & $p$-value & $\begin{array}{l}\text { Adjusted PR } \\
95 \% \text { CI }\end{array}$ & $p$-value & $\begin{array}{l}\text { Adjusted PR } \\
95 \% \text { CI }\end{array}$ & $\begin{array}{l}p \text { - } \\
\text { value }\end{array}$ \\
\hline $\begin{array}{l}\text { Jender } \\
\text { Male } \\
\text { Female }\end{array}$ & $\begin{array}{l}1.07(0.98 ; 1.14) \\
1\end{array}$ & 0.17 & $\begin{array}{l}0.94(0.80 ; 1.11) \\
1\end{array}$ & 0.47 & $\begin{array}{l}1.07(0.86 ; 1.18) \\
1\end{array}$ & 0.11 & $\begin{array}{l}0.99(0.84 ; 1.16) \\
1\end{array}$ & 0.90 & $\begin{array}{l}1.06(0.98 ; 1.14) \\
1\end{array}$ & 0.15 \\
\hline $\begin{array}{l}\text { Mother } \\
\text { ?ducation } \\
\text { years) } \\
\text { (9 } \\
\geq 9 \\
\end{array}$ & $\begin{array}{l}1.21(1.06 ; 1.24) \\
1\end{array}$ & 0.002 & & & $\begin{array}{l}1.58(1.27 ; 1.95) \\
1\end{array}$ & $\square 0.0001$ & $\begin{array}{l}1.56(1.25 ; 1.95) \\
1\end{array}$ & $\square 0.0001$ & $\begin{array}{l}1.41(1.14 ; 1.74) \\
1\end{array}$ & 0.006 \\
\hline $\begin{array}{l}\text { School type } \\
\text { ?ublic } \\
\text { ?rivate } \\
\end{array}$ & $\begin{array}{l}1.14(1.09 ; 1.29) \\
1\end{array}$ & 0.01 & & & $\begin{array}{l}1.34(1.09 ; 1.64) \\
1\end{array}$ & 0.006 & $\begin{array}{l}1.48(1.18 ; 1.85) \\
1\end{array}$ & 0.001 & $\begin{array}{l}1.27(1.17 ; 1.38) \\
1\end{array}$ & 0.02 \\
\hline $\begin{array}{l}\text { Tousehold } \\
\text { 3xpenditure } \\
\text { |3.20\$/day } \\
\geq 3.20 \text { \$ / day }\end{array}$ & $\begin{array}{l}1.16(1.06 ; 3.19) \\
1\end{array}$ & 0.02 & & & $\begin{array}{l}1.21(1.03 ; 1.33) \\
1\end{array}$ & 0.018 & $\begin{array}{l}1.23(1.11 ; 1.39) \\
1\end{array}$ & 0.01 & $\begin{array}{l}1.22(1.12 ; 1.49) \\
1\end{array}$ & 0.04 \\
\hline $\begin{array}{l}\text { Cooth } \\
\text { srushing } \\
\text { rregular } \\
\text { Regular }\end{array}$ & $\begin{array}{l}1.21(1.06 ; 1.49) \\
1\end{array}$ & 0.05 & & & & & $\begin{array}{l}1.02(0.75 ; 1.15) \\
1\end{array}$ & 0.51 & $\begin{array}{l}1.14(0.80 ; 1.84) \\
1\end{array}$ & 0.46 \\
\hline $\begin{array}{l}\text { Jental } \\
\text { zppointments } \\
\text { No } \\
\text { Yes } \\
\end{array}$ & $\begin{array}{l}1.11(1.05 ; 1.23) \\
1\end{array}$ & 0.03 & & & & & $\begin{array}{l}1.20(1.04 ; 1.29) \\
1\end{array}$ & 0.04 & $\begin{array}{l}1.25(1.16 ; 1.46) \\
1\end{array}$ & 0.004 \\
\hline $\begin{array}{l}\text { Mouth wash } \\
\text { lse } \\
\text { No } \\
\text { Yes }\end{array}$ & $\begin{array}{l}1.03(0.79 ; 1.33) \\
1\end{array}$ & 0.85 & & & & & $\begin{array}{l}1.08(0.89 ; 1.94) \\
1\end{array}$ & 0.14 & $\begin{array}{l}1.18(0.89 ; 1.84) \\
1\end{array}$ & 0.19 \\
\hline $\begin{array}{l}\text { Jental floss } \\
\text { ıse } \\
\text { No } \\
\text { Yes } \\
\end{array}$ & $\begin{array}{l}1.07(0.70 ; 1.22) \\
1\end{array}$ & 0.30 & & & & & $\begin{array}{l}1.12(0.91 ; 1.28) \\
1\end{array}$ & 0.48 & $\begin{array}{l}1.05(0.8 ; 1.36) \\
1\end{array}$ & 0.73 \\
\hline
\end{tabular}

PR: Prevalence Ratio

Table 4. Mean of Decayed, Missed, Filled (DMFT) index and decayed teeth (DT) scores in relation to demographic, socioeconomic, dental care, relation 


\begin{tabular}{|c|c|c|}
\hline Predictors & $\mathrm{CPQ}_{11-14}$ Mean (SD) scores & $p$-value* \\
\hline $\begin{array}{l}\text { Gender } \\
\text { Male } \\
\text { Female }\end{array}$ & $\begin{array}{l}38.07(12.60) \\
42.20(10.49)\end{array}$ & $\square 0.0001$ \\
\hline $\begin{array}{l}\text { Age (years) } \\
12 \\
13 \\
14\end{array}$ & $\begin{array}{l}40.96(12.14) \\
42.82(9.64) \\
41.32(12.66)\end{array}$ & 0.13 \\
\hline $\begin{array}{l}\text { School type } \\
\text { Public } \\
\text { Private }\end{array}$ & $\begin{array}{l}44.64(8.28) \\
30.16(12.18)\end{array}$ & $\square 0.0001$ \\
\hline $\begin{array}{l}\text { Mother education (years) } \\
\geq 9 \\
\square 9\end{array}$ & $\begin{array}{l}40.46(11.67) \\
38.13(11.50)\end{array}$ & 0.014 \\
\hline $\begin{array}{l}\text { Household expenditure } \\
\square 3.20 \$ \text { /day } \\
\leq 3.20 \text { \$ day }\end{array}$ & $\begin{array}{l}36.36(13.26) \\
45.06(6.94)\end{array}$ & $\square 0.0001$ \\
\hline $\begin{array}{l}\text { Tooth brushing frequency } \\
\text { Irregular } \\
\text { Regular }\end{array}$ & $\begin{array}{l}41.73(11) \\
35.33(12.56)\end{array}$ & $\square 0.0001$ \\
\hline $\begin{array}{l}\text { Mouth washing frequency } \\
\text { Irregular } \\
\text { Regular }\end{array}$ & $\begin{array}{l}40.79(11.46) \\
34.77(12.68)\end{array}$ & $\square 0.0001$ \\
\hline $\begin{array}{l}\text { Dental appointment per year } \\
\text { No } \\
\text { Yes }\end{array}$ & $\begin{array}{l}43.40(9.41) \\
34.67(13.23)\end{array}$ & $\square 0.0001$ \\
\hline $\begin{array}{l}\text { Dental floss use } \\
\text { No } \\
\text { Yes }\end{array}$ & $\begin{array}{l}40.65(11.55) \\
38.73(12.10)\end{array}$ & 0.076 \\
\hline $\begin{array}{l}\text { DMFT } \\
\leq 3 \\
\square 3\end{array}$ & $\begin{array}{l}34.05(12.46) \\
42.22(10.14)\end{array}$ & 0.002 \\
\hline $\begin{array}{l}\text { DT } \\
0 \\
\geq 1\end{array}$ & $\begin{array}{l}27.66(12.76) \\
45.48(5.81)\end{array}$ & $\square 0.0001$ \\
\hline
\end{tabular}

*Independent-Sample T test; One Way (ANOVA)

Table 5. Perceived oral health related quality of life (OHRQoL) based on the scores of child perception questionnaire $\mathrm{CPQ}_{11-14}$ domains

\begin{tabular}{|l|l|l|l|}
\hline $\mathrm{Q}_{11-14}$ domains & Mean (SD) & Median (IQR) & Cronbach's alpha \\
\hline al symptoms (OS) & $11.16 \pm 3.58$ & $12(4.75)$ & 0.71 \\
\hline nctional limitations (FL) & $10.45 \pm 3.25$ & $11(5)$ & 0.67 \\
\hline 1otional well-being (EW) & $10.15 \pm 3.42$ & $11(5)$ & 0.61 \\
\hline cial well-being (SW) & $9.75 \pm 2.98$ & $10(3)$ & 0.67 \\
\hline erall score & $42.40 \pm 11.63$ & $43(11.75)$ & 0.84 \\
\hline
\end{tabular}

Table 6. Multiple regression analysis of factors influencing oral health related quality of life (OHRQoL) in 11 to 14 years school children 


\begin{tabular}{l|l|l|l|l|}
\hline redictors & $\beta$ & $95 \%$ CI & $p$-value & Adjusted $\mathrm{R}^{2}$ \\
\hline tep 1 & 0.18 & $2.75 ; 5.58$ & $\square 0.0001$ & 0.04 \\
Gender & -0.83 & $-1.67 ;-0.26$ & 0.007 & \\
Age (years) & 0.08 & $0.68 ; 2.98$ & 0.002 & 0.38 \\
\hline tep 2 & -0.02 & $-0.82 ; 0.31$ & 0.38 & \\
Gender & 0.16 & $2.30 ; 5.01$ & $\square 0.0001$ & \\
Age (years) & -0.54 & $-15.34 ;-12.38$ & $\square 0.0001$ & \\
Household expenditure & -0.23 & $-8.42 ;-5.30$ & $\square 0.0001$ & \\
School type & & & & \\
Mother education & 0.08 & $075 ; 3.05$ & 0.001 & 0.4 \\
tep 3 & -0.2 & $-0.79 ; 0.33$ & 0.43 & \\
Gender & 0.14 & $1.99 ; 4.67$ & $\square 0.0001$ & \\
Age (years) & -0.5 & $-14.26 ;-11.04$ & $\square 0.0001$ & \\
Household expenditure & -0.22 & $-8.18 ;-5.04$ & $\square 0.0001$ & \\
School type & -0.05 & $-5.24 ; 0.16$ & 0.07 & \\
Mother education & -0.11 & $-1.59 ; 0.56$ & $\square 0.0001$ & \\
Mouth washing frequency & -0.07 & $-3.15 ;-0.21$ & 0.025 & \\
Tooth brushing frequency & -0.07 & $-2.21 ;-0.17$ & 0.014 & \\
Dental appointment & & & & \\
Dental floss use & -0.03 & $-1.54 ; 0.28$ & 0.17 & 0.64 \\
tep 4 & -0.03 & $-0.77 ; 0.09$ & 0.12 & \\
Gender & 0.07 & $0.62 ; 2.70$ & 0.002 & \\
Age (years) & -0.38 & $-10.97 ;-8.45$ & $\square 0.0001$ & \\
Household expenditure & -0.17 & $-6.36 ;-3.93$ & $\square 0.0001$ & \\
School type & -0.04 & $-3.89 ; 0.28$ & 0.09 & \\
Mother education & -0.07 & $-1.05 ;-0.26$ & 0.001 & \\
Mouth washing frequency & -0.08 & $-1.58 ; 0.73$ & 0.47 & \\
Tooth brushing frequency & -0.05 & $-1.53 ; 1.44$ & 0.95 & \\
Dental appointment & 0.02 & $-0.34 ; 1.45$ & 0.23 & \\
Dental floss use & 0.54 & $12.88 ; 15.03$ & $\square 0.0001$ & \\
DMFT & & & & \\
DT & & & \\
\hline
\end{tabular}

\section{Figures}


${ }^{*}$ The number of students between 12 and 14 years in the Minia City (study target) =

55,979

Boys $=28,634$

Girls $=27,345$

*Total number preparatory schools in the

Minia City

Public $=18$

Private $=6$

${ }^{*}$ Schools are distributed on 6 districts

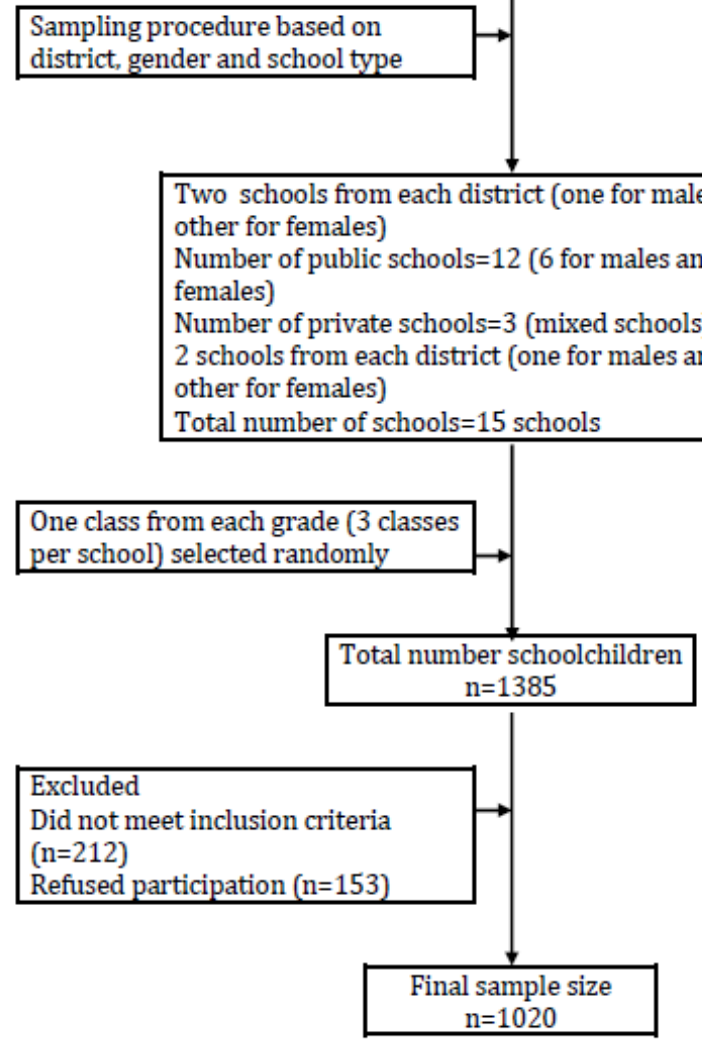

\section{Figure 1}

Multistage sampling procedures 


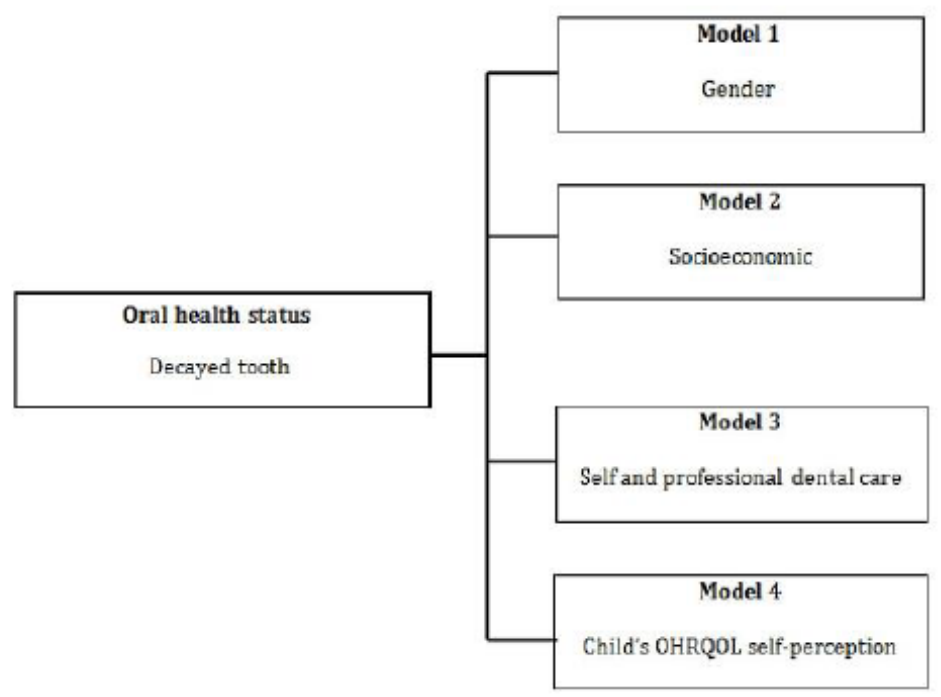

Figure 2

A conceptual model was released according to a hierarchy approach of determinants and risk factors and it was structured according to the model made by Paula et al.

\section{Supplementary Files}

This is a list of supplementary files associated with this preprint. Click to download.

- STROBEchecklistv4combined.pdf 